\title{
Integrated Learning in Engineering - Development of the First Year Engineering Curriculum at UNB
}

\author{
Michel Couturier, Dawn MacIsaac and Liuchen Chang \\ Faculty of Engineering, University of New Brunswick, Fredericton, NB E3B 5A3 \\ Tel: (506) 453-4690 E-mail cout@unb.ca
}

\begin{abstract}
Following its rich tradition of over 150 years of excellence in engineering education, the Faculty of Engineering at the University of New Brunswick (UNB) is currently implementing an exciting first year program. In consultation with Atlantic businesses, governments and members of the Faculty, an Engineering Education Task Force was formed in the summer of 2003 with the mandate to enhance integrated learning in undergraduate engineering programs at UNB. The Task Force proposed a substantially-common first year program for all engineering disciplines with design projects in both the first and second terms. The design projects are used to integrate knowledge gained in the first year and are part of two new design courses. The first design course is centered on Design and Communications. The second design course is centered on Design and Computations. This new approach requires that teaching of core materials be integrated at a level that crosses disciplinary boundaries.
\end{abstract}

Topics: Design Education, Design Curriculum

\section{Introduction}

Accreditation bodies, scientific councils and the business community are calling for deep changes in engineering education. According to these groups, engineering curricula must continue to provide a strong scientific training but must also emphasize the development of business, design, communication, project management and team-work skills. In response to these requests, the Faculty of Engineering at the University of New Brunswick (UNB) set up an Engineering Education Task Force in the summer of 2003 with the mandate of examining the first year curriculum and making recommendations for improvement. The Task Force was created as a subcommittee of the Faculty of Engineering's Curriculum Committee with membership from the 9 engineering programs of the Faculty.
After a critical evaluation of emerging trends in Engineering education and four months of brainstorming activities, the Task Force recommended a major reorganization of the first-year program. The vision proposed by the Task Force was approved in principle by Faculty Council in the spring of 2004 and several sub-committees were established shortly thereafter to work out the details of the vision. All members of the Faculty were called upon to participate and voice their opinions. Multi-disciplinary teams of professors from the Faculties of Engineering, Science and Computer Science worked on the development of the proposed curriculum of integrated learning and detailed courses.

This paper summarizes the rationale for the proposed changes and presents a detailed description of the first of the two design courses in the new first-year program.

\section{Objectives}

The proposed first year was developed with the following objectives in mind:

- offer a core set of courses that will provide all engineering students with a solid understanding of basic scientific and engineering principles;

- help students confirm their career choice early by promoting a better understanding of the role of engineers in society and the different engineering disciplines;

- develop an innovative curriculum which helps students integrate knowledge;

- enhance design content of our programs;

- emphasize importance of communication skills, team work, project management, business skills;

- improve students' chances of success by increasing student support (e.g. by reducing class sizes). 


\section{Constraints}

Several constraints defined the boundaries within which the Task Force and its sub-committees had to work:

- Changes must be implemented by re-deploying existing resources.

- Eliminate overlap among courses (i.e. redundancy in course materials) in favor of integration of course materials in a given term and between courses in different terms. This should result in more interesting courses whose relevancy should no longer be questioned.

- Minimize the penalty (in credit hours) inflicted on students who want to switch to a different engineering program after the first year.

- Meet the needs of students in all 9 programs (Chemical, Civil, Computer, Electrical, Forestry, Geodesy and Geomatics, Geological, Mechanical, Software Engineering).

\section{Proposed $1^{\text {st }}$ Year Program}

The proposed framework for the $1^{\text {st }}$ Year of Engineering at UNB is presented in Table 1.

Table 1 Framework of the First Year Curriculum

\begin{tabular}{|lc|lr|}
\hline Fall Term & $(\mathrm{ch})$ & Winter Term $^{*}$ & (ch) \\
\hline Mechanics I & $(5)$ & Mechanics II & $(5)$ \\
\hline Calculus I & $(3)$ & Calculus II & $(3)$ \\
\hline Linear Algebra & $(3)$ & Chemistry & $(5)$ \\
\hline \multicolumn{2}{|l|}{ Program Specific Elective } & Electricity \& Magnetism \\
& $(3)$ & & $(4)$ \\
\hline $\begin{array}{l}\text { Design and } \\
\text { Communications }\end{array}$ & $(6)$ & Design and \\
\hline Total credit hours & $(20)$ & Total credit hours & $(20)$ \\
\hline
\end{tabular}

* Programs may elect to substitute one of the courses in the winter term, excluding Design and Computations, with a program specific elective.

Unique features of the proposed first-year program include:

- Building on the experience of other innovative engineering programs across Canada, the proposed program uses mini design projects in each term to integrate knowledge learned in prerequisite or co-requisite courses. This new approach requires that teaching of core materials be integrated at a level that crosses disciplinary boundaries. The newly developed courses Mechanics I and II were created in collaboration with the Faculty of Science by integrating concepts previously taught in the following courses: Physics for Engineers, Statics and Dynamics. Overlap among these courses was thereby eliminated. A multi-disciplinary team consisting of professors from Physics, Mechanical Engineering and Civil Engineering has been formed to teach the new Mechanics I and II courses.

- Use of computers is emphasized throughout the program. Matlab is introduced as a convenient platform for solving sets of linear equations in Linear Algebra and will be integrated into most courses. Algorithm and code development is taught in the second design course of Design and Computations.

- New common courses were created to help students acquire important design and other skills in an early stage of learning (Design and Communications \& Design and Computations). It is expected that all programs will continue the development of these skills in subsequent years. This approach will provide students with more time to hone and master these skills before graduation.

- The program will not only continue to emphasize acquisition of knowledge (basic and engineering sciences) but also develop competencies (knowhow) and attitudes (team work, perseverance, creativity, professionalism, ethics, etc.).

\section{Implementation Timetable}

The Faculty of Engineering opted to implement the revised first-year program in stages. The teamtaught Mechanics I and II courses along with the new Electricity and Magnetism course were offered for the first time during the 2004-2005 academic year. The new Design and Communications course will be offered for the first time in the fall of 2005 and the new Design and Computations course will be implemented in the winter of 2006. Other courses will be modified as we introduce the design courses to ensure integration. Full implementation of the new first-year program will be achieved in the 2006/2007 academic year.

\section{Design and Communications}

Given the learning objectives proposed for the new curriculum of the first year, and the role of the Design and Communications course in meeting those objectives, the following learning outcomes are proposed for this course. By the end of the course, students will be able to: 
- design at an elementary level with concepts of idea generation, conceptual design, detailed design and design verification;

- interpret, apply, verify and work professional specifications;

- $\quad$ present design graphically by generating graphics both manually and with computer tools;

- synthesize, analyze and critique designs and written and oral documents;

- $\quad$ reference properly;

- find and assess information sources within and external to the university environment and gather information from these sources;

- work effectively in diverse teams by being an active team member, assessing individual and group team performance, reacting constructively to assessments and demonstrating knowledge of team roles, responsibilities and functions that help team members work together effectively;

- $\quad$ assess and react constructively to being assessed;

- describe what various engineers do;

- $\quad$ uphold the responsibilities associated with being a professional engineer, especially within the context of being a student (attitude, behavior, ethics).

All of the outcomes for this course are related to engineering design. Communication, teamwork, professionalism, knowledge of engineering disciplines and assessment, all enhance an engineer's ability to design, and collectively form the basis of a coherent and relevant engineering course. Thus, the general approach to the course is to use a design project as a medium for introducing students to important engineering skills. Since the course is offered in Year 1 , the focus is on elementary design. Students will learn about, and get a chance to practice idea generation and brainstorming, conceptual designs and modeling, and take part in activities related to working out design details, and design verification.

To meet the demands of the course, nine units have been proposed, the contents of which are all integrated through a common team design project. Students will work in teams of four and call upon what they are learning in co-requisite courses to complete the project. The project will change from year to year but in order to adhere to the integrative and design intent of the course, it must have the following characteristics:

- the project must contain some mechanicallyoriented components;

- $\quad$ the project must contain components which can be mathematically modeled and some components which can be physically modeled at an appropriate level for the first year students;

- $\quad$ students must be able to build physically modeled components without the use of university machine shop facilities;

- the project must be sufficiently complex to allow for multiple iterations of conceptual designs;

- the project must be sufficiently open-ended to ensure multiple solutions.

As an example, the project proposed for the coming year involves an opportunity to improve the lifestyle of a remote community in a developing country which currently extends significant human effort in extracting water from its main water source, a natural well $40 \mathrm{~m}$ below ground.

To guide students through the project and other learning activities, a set of milestones have been established based on the learning outcomes proposed, and three different assessment strategies have been adopted to ensure that learning outcomes have been met. Table 2 delineates how each milestone (row headers) contributes to assessment within the nine units (column headers) which make up the course.

As indicated in Table 2, the three strategies for assessment of students include a percentage, a level and a pass/fail threshold $(\mathrm{P} / \mathrm{F})$. The Design component of the course will be assessed with a percentage grade based on the contents of the milestones submitted. The Writing, Presentations, and Graphics components will be assessed with a level defined by a rubric for each component based on the style of the milestones submitted. As an example, the Writing rubric is presented in Table 3. The Teams and Assessment components will also be assessed with a level and a rubric, but the rubric will be contents-based rather than style-based. That is, in evaluating for Assessment for instance, the contents of the milestone will be assessed rather than the style with which the information is presented. Finally, the Information Sources and Getting the Most from your Education (GME) Components will be evaluated merely by a pass/fail threshold. Each student's final grade for the course will be set based on a set of criteria involving all 9 units. For instance, to get an $\mathrm{A}+$ in the course, a student would have to earn over 90 in the Design component, a pass in both Information Sources and GME and top levels in all of the other units.

Learning activities for this course have been developed according to Kolb's learning paradigm [1]. This paradigm involves a cyclic relationship between four processes: Concrete Experience, Reflective 
Observation, Abstract Conceptualization, and Active Experimentation. This paradigm is especially effective for teaching design, since students often gravitate to these processes when designing, although seldom with sufficient attention to the second and third elements of the cycle. To ensure that students are able to experience sufficient aspects of these processes with appropriate guidance, the course has been structured with a focus on lab/tutorial contact hours. In total, the course offers students nine contact hours per week three in lectures, three in tutorials and three in labs. In lectures, all students will come together to learn theoretical aspects of course material. In tutorials, students are split into small sections $(<25$ students $)$ so that small group experiential activities can take place. For instance, in one of the Teams tutorials, students will take part in role playing exercises which demonstrate team blocking behaviors and strategies for overcoming these behaviors. Finally, in labs, these same sections will participate in graphic and design activities, all related to the team design project.

\section{Conclusion}

Considering recommendations from Atlantic businesses, governments and members of the Faculty, and building on the experience of other innovative engineering programs across Canada, the Faculty of Engineering of UNB has embarked the development of an innovative first year curriculum. The Engineering Education Task Force was formed to take on the task of improving the first year curriculum and developing detailed courses, which has proved to be an effective approach for such a complex task. To achieve the goal of integrated learning through engineering design, a substantially-common first year curriculum have been proposed, and a number of new courses have been developed or are under development, including new Mechanics I and II, Electricity and Magnetism, Design and Communications, and Design and Computations. The new first year curriculum is in the process of multi-stage implementation. The development process and outcomes have provided an opportunity for the involvement and collaboration of all engineering education stakeholders, and will contribute to the success of our students.

\section{8. $\quad$ Reference}

1. Kolb, D. A. (1984). Experiential learning: Experience as the source of learning and development. Englewood Cliffs, NJ: Prentice Hall, 1984.

Table 2 Assessment of the First Design Course - Design and Communications

\begin{tabular}{|c|c|c|c|c|c|c|c|c|c|}
\hline & Design & Writing & \begin{tabular}{|l|} 
Presentations \\
\end{tabular} & Graphics & \begin{tabular}{|l|} 
Info Sources \\
\end{tabular} & Profession & Teams & Assessment & GME* $^{*}$ \\
\hline \begin{tabular}{l}
\multicolumn{1}{c}{ Initial Design } \\
Design Document \\
Presentation \\
Engineering type \\
Contribution Analysis \\
Peer Assessment
\end{tabular} & Contents & $\begin{array}{l}\text { Style } \\
\text { Style } \\
\text { Style }\end{array}$ & Style & Style & Usage/Style & Contents & & Contents & \\
\hline Problem Definition & & & & & & & & & \\
\hline Requirements Document & Contents & Style & & & Usage/Style & & & & \\
\hline Mathematical Model & Contents & Style & & Style & Usage/Style & & & & \\
\hline $\begin{array}{c}\text { Verification } \\
\text { Test Plan/Results }\end{array}$ & Contents & Style & & Style & & & & & \\
\hline Lab Report & Contents & Style & & Style & Usage/Style & & & & \\
\hline $\begin{array}{l}\quad \text { Final Design } \\
\text { Design Document } \\
\text { Presentation } \\
\text { Peer Assessment }\end{array}$ & $\begin{array}{l}\text { Contents } \\
\text { Contents }\end{array}$ & $\begin{array}{l}\text { Style } \\
\text { Style }\end{array}$ & Style & Style & Usage/Style & & & Contents & \\
\hline Guest Speaker Review & & Style & & & & Contents & & & \\
\hline $\begin{array}{l}\text { Report on an Engineer } \\
\text { Document } \\
\text { Presentation }\end{array}$ & & Style & Style & & Usage/Style & Contents & & & \\
\hline Progress Reports & & Style & & & & & Contents & & \\
\hline Video on Team Behavior & & & & & & & Contents & & \\
\hline \begin{tabular}{l}
\multicolumn{1}{c}{ Log-book } \\
General (including design \\
details) \\
Team Assessments \\
(including self, and peer) \\
Reflections (including \\
learning and assessment)
\end{tabular} & & & & & & $\begin{array}{l}\text { Contents } \\
\text { Contents } \\
\text { Contents }\end{array}$ & $\begin{array}{l}\text { Contents } \\
\text { Contents }\end{array}$ & Contents & Contents \\
\hline Assessment Strategy & $\%$ & Level & Level & Level & $\overline{\mathrm{P} / \mathrm{F}}$ & Level & $\overline{\mathrm{P} / \mathrm{F}}$ & Level & P/F \\
\hline
\end{tabular}

* GME - Getting the Most out of Your Education 
Table 3 Technical Writing Rubric

\begin{tabular}{|c|c|c|c|c|c|c|c|}
\hline & Structure & $\begin{array}{l}\text { Spelling and } \\
\text { Grammar }\end{array}$ & Clarity & Succinctness & Content & References & Level of Sophistication \\
\hline 1 & $\begin{array}{l}\text { content is not sectioned } \\
\text { appropriately; } \\
\text { equations/tables/ figures } \\
\text { are not labeled } \\
\text { appropriately; sections } \\
\text { may not be clearly } \\
\text { indicated; the document } \\
\text { may be too long or too } \\
\text { short }\end{array}$ & $\begin{array}{l}\text { content is } \\
\text { unintelligible } \\
\text { throughout due } \\
\text { to spelling } \\
\text { and/or } \\
\text { grammatical } \\
\text { errors }\end{array}$ & $\begin{array}{l}\text { content is } \\
\text { unintelligible } \\
\text { throughout due } \\
\text { to incoherent or } \\
\text { uncoordinated } \\
\text { ideas, or } \\
\text { inconsistencies }\end{array}$ & $\begin{array}{l}\text { document is not } \\
\text { succinct; filled } \\
\text { with irrelevant } \\
\text { ideas and vague } \\
\text { words requiring } \\
\text { further } \\
\text { explanation }\end{array}$ & $\begin{array}{l}\text { Insufficient } \\
\text { breadth and } \\
\text { depth } \\
\text { throughout }\end{array}$ & $\begin{array}{l}\text { No references } \\
\text { where } \\
\text { references were } \\
\text { required }\end{array}$ & $\begin{array}{l}\text { Many exaggerations or weak statements, run on } \\
\text { sentences, fragmented ideas; may have used } \\
\text { ambiguous, useless, redundant, semantically } \\
\text { incorrect words, poor verb structure, } \\
\text { personification, undefined abbreviations, } \\
\text { passive voice, sentences ending in prepositions, } \\
\text { typos; may be missing connective or transition } \\
\text { words }\end{array}$ \\
\hline 2 & $\begin{array}{l}\text { content is sectioned; } \\
\text { major mandatory } \\
\text { sections missing or } \\
\text { misrepresented; } \\
\text { equations/tables/ figures } \\
\text { are not labeled } \\
\text { consistently; ;sections } \\
\text { may not be clearly } \\
\text { indicated; sections may } \\
\text { be inconsistently } \\
\text { indicated }\end{array}$ & $\begin{array}{l}\text { content is } \\
\text { unintelligible in } \\
\text { places due to } \\
\text { many spelling } \\
\text { and/or } \\
\text { grammatical } \\
\text { errors }\end{array}$ & $\begin{array}{l}\text { content is } \\
\text { unintelligible in } \\
\text { places because } \\
\text { of many } \\
\text { incoherent or } \\
\text { uncoordinated } \\
\text { ideas, or } \\
\text { inconsistencies }\end{array}$ & $\begin{array}{l}\text { document is not } \\
\text { succinct; many } \\
\text { irrelevant ideas } \\
\text { and vague } \\
\text { words requiring } \\
\text { further } \\
\text { explanation }\end{array}$ & $\begin{array}{l}\text { Sufficient } \\
\text { breadth/depth } \\
\text { throughout; } \\
\text { insufficient } \\
\text { depth/breadth }\end{array}$ & $\begin{array}{l}\text { Missing } \\
\text { references } \\
\text { where } \\
\text { references were } \\
\text { required }\end{array}$ & $\begin{array}{l}\text { regular use of ambiguous, useless, redundant, } \\
\text { semantically incorrect words; poor verb structure; } \\
\text { may have used personification, undefined } \\
\text { abbreviations, passive voice, sentences ending in } \\
\text { prepositions, typos; may be missing connective or } \\
\text { transition words }\end{array}$ \\
\hline 3 & $\begin{array}{l}\text { content is sectioned; } \\
\text { minor mandatory } \\
\text { sections missing or } \\
\text { misrepresented; a few } \\
\text { equations/tables/ figures } \\
\text { may be mislabeled }\end{array}$ & $\begin{array}{l}\text { content } \\
\text { intelligible; a } \\
\text { few major } \\
\text { spelling and/or } \\
\text { grammatical } \\
\text { errors }\end{array}$ & $\begin{array}{l}\text { content is } \\
\text { intelligible; a } \\
\text { few incoherent } \\
\text { or } \\
\text { uncoordinated } \\
\text { ideas, or } \\
\text { inconsistencies }\end{array}$ & $\begin{array}{l}\text { document is } \\
\text { succinct; some } \\
\text { irrelevant ideas }\end{array}$ & $\begin{array}{l}\text { insufficient } \\
\text { breadth and } \\
\text { depth relating } \\
\text { to some content }\end{array}$ & $\begin{array}{l}\text { Incorrect } \\
\text { referencing } \\
\text { format }\end{array}$ & $\begin{array}{l}\text { use of personification, undefined abbreviations; } \\
\text { missing connective or transition words; may have } \\
\text { used sentences ending in prepositions, typos; may } \\
\text { be inappropriately passive }\end{array}$ \\
\hline 4 & $\begin{array}{l}\text { content is sectioned; } \\
\text { fewer or more sections } \\
\text { would increase } \\
\text { intelligibility; a few } \\
\text { equations/tables/ figures } \\
\text { may be mislabeled }\end{array}$ & $\begin{array}{l}\text { content is } \\
\text { intelligible; } \\
\text { some minor } \\
\text { spelling or } \\
\text { grammatical } \\
\text { errors }\end{array}$ & $\begin{array}{l}\text { content is } \\
\text { intelligible; a } \\
\text { few } \\
\text { inconsistencies }\end{array}$ & $\begin{array}{l}\text { document is } \\
\text { succinct; some } \\
\text { phrases where } \\
\text { single words } \\
\text { would suffice }\end{array}$ & $\begin{array}{l}\text { sufficient } \\
\text { breadth/depth } \\
\text { relating to some } \\
\text { content; } \\
\text { insufficient } \\
\text { breadth/depth } \\
\text { relating to other } \\
\text { content }\end{array}$ & $\begin{array}{l}\text { referencing } \\
\text { format } \\
\text { generally } \\
\text { acceptable; a } \\
\text { few formatting } \\
\text { issues }\end{array}$ & $\begin{array}{l}\text { Inappropriately more passive than active; } \\
\text { sentences ending in prepositions; a few typos; a } \\
\text { few semantic errors in word choice }\end{array}$ \\
\hline 5 & $\begin{array}{l}\text { all content is } \\
\text { appropriately sectioned }\end{array}$ & $\begin{array}{l}\text { content is } \\
\text { intelligible; no } \\
\text { consequential } \\
\text { spelling or } \\
\text { grammatical } \\
\text { errors }\end{array}$ & $\begin{array}{l}\text { content is } \\
\text { intelligible; } \\
\text { coherent, } \\
\text { coordinated and } \\
\text { consistent } \\
\text { throughout }\end{array}$ & $\begin{array}{l}\text { document is } \\
\text { succinct; all } \\
\text { words are } \\
\text { specific and } \\
\text { necessary; all } \\
\text { ideas are } \\
\text { relevant }\end{array}$ & $\begin{array}{l}\text { sufficient } \\
\text { breadth and } \\
\text { depth } \\
\text { throughout }\end{array}$ & $\begin{array}{l}\text { Documentation } \\
\text { properly } \\
\text { referenced }\end{array}$ & $\begin{array}{l}\text { Level of sophistication suitable for a university } \\
\text { audience }\end{array}$ \\
\hline
\end{tabular}

